\title{
Bio-Oil dari Limbah Padat Sawit dengan Metoda Pirolisa
}

\author{
Edy Saputra*) dan Syaiful Bahri \\ Laboratorium Teknik Reaksi Kimia, Fakultas Teknik, Universitas Riau \\ Kampus Bina Widya km 12,5 Pekanbaru 28293
}

Diterima 20-01-2008 Disetujui 21-02-2009

\begin{abstract}
Bio oil is most important alternative energy resources for human life due to the production of fossil fuel tend to decline. Numbers of researches have been developed on alternative energy resources, such as the conversion of biomass. The palm solid waste which is consisted of wood, stem and empty bunch having size of diameter in range of 2 to 10 mesh were used in this work. The pyrolysis method is selected in this research. This process was done in stainless steel reactor having length and length of 60.0 and $3.81 \mathrm{~cm}$ respectively at temperature of 450 to $600^{\circ} \mathrm{C}$ under nitrogen flow. Gas chromatography HP 5890 is utilized to analyze of the bio oil result. The result achieved the highest yield at $500^{\circ} \mathrm{C}$ and particle diameter of 2-6 mesh.
\end{abstract}

Keywords: Bio oil, Pyrolysis, Palm Solid Waste

\section{PENDAHULUAN}

Kenyataan bahwa cadangan bahan bakar fosil (minyak bumi) dunia semakin menipis, tidak dapat dielakkan lagi. Kondisi ini memaksa para peneliti di dunia untuk mendapatkan energi alternatif yang dapat mengurangi beban suplai energi berbasis minyak bumi. Selain itu sejak diberlakukannya Protokol-Kyoto tahun 2005 mengenai kehawatiran masyarakat dunia terhadap perubahan iklim global akibat pemakaian bahan bakar fosil juga mendorong pencarian alternatif sumber energi yang ramah lingkungan. Harapannya energi yang digunakan di masa akan datang merupakan sumber energi yang baru dan terbarukan, yang lebih ramah lingkungan tidak menambah parah terjadinya polusi udara, terutama timbulnya emisi gas $\mathrm{CO}_{x}, \mathrm{NO}_{x}$ dan $\mathrm{SO}_{x}$.

Pada dasawarsa 70 -an dan sebelumnya, minyak dan gas bumi telah memainkan peranan penting dalam penyumbang devisa bagi negara dan menjadi andalan ekspor Indonesia. Keadaan ini tidak dapat lagi dipertahankan pada dasawarsa 90-an. Bahkan pada abad 21 sekarang ini Indonesia diperkirakan akan menjadi net importir bahan bakar fosil (Kartasasmita 1992). Sumber energi alternatif sudah saatnya untuk dikembang di Indonesia, salah satunya mengolah biomasa sebagai limbah perkebunan dan pertanian menjadi sumber energi bahan bakar cair yang dapat terbarukan.

\footnotetext{
*Telp: 0815371770774

Email: edy@unri.ac.id, sbahri@unri.ac.id
}

Pada saat sekarang telah banyak dilakukan penelitian yang berkaitan dengan bahan bakar alternatif pengganti minyak bumi, seperti penelitian yang dilakukan oleh Beis et al, (2002), Ozbay et al, (2001) dan Onay et al, (2004) yaitu mengkonversikan biomas menjadi produk bio-oil. Goyal et al, (2006), melaporkan bahwa bio-oilmerupakan salah satu sumber energi yang dapat terbaharukan yang sangat menjanjikan yang dapat digunakan untuk industri seperti combustion fuel, power generation, untuk memproduksi bahan kimia, resin, anhydro-sugars dan dapat dicampur dengan minyak diesel sebagai bahan bakar mesin diesel dengan campuran tertentu.

Biomasa yang digunakan untuk memproduksi biooil dapat diperoleh dari limbah pertanian, hutan, perkebunan, industri dan rumah tangga. Negara tropis seperti Indonesia umumnya mempunyai biomasa yang berlimpah, kira-kira 250 milyar ton/tahun dihasilkan dari biomasa hutan dan limbah pertanian. Limbah pertanian secara umum berasal dari perkebunan kelapa sawit, tebu, kelapa serta sisa panen dan lain-lainnya yang mencapai kira-kira 40 milyar ton/tahun (Suwono 2003). Dari estimasi potensi limbah perkebunan dari tahun 2001-2003, Panaka melaporkan bahwa di Indonesia limbah kelapa sawit mempunyai potensi yang lebih besar dibandingkan dengan batang karet, kelapa dan tebu. Dengan perbandingan kelapa sawit 48,6 juta ton/tahun; batang karet 2,6 juta ton/tahun; kelapa 3,9 juta ton/tahun; tebu 0,14 juta ton/tahun. Potensi yang besar ini karena Indonesia memiliki perkebunan kelapa 
sawit sekitar 4 juta Ha dengan total produksi 8 juta ton CPO dan Kernel (Suwono 2003).

Berdasarkan data BPS tahun 2004 dari 4 juta $\mathrm{Ha}$ perkebunan tersebut, sekitar 1.231.323 Ha berada di Propinsi Riau. Luasnya lahan kebun kelapa sawit akan menghasilkan limbah padat sawit yang sangat banyak. Limbah padat sawit yang dihasilkan dapat berupa cangkang, batang, tandan kosong, pelepah dan lainlain merupakan sisa dari industri sawit yang belum dimanfaatkan secara optimal. Selama ini, limbah padat sawit di bakar di lahan dan menghasilkan abu yang digunakan sebagai pupuk tanaman (Suwono 2003). Selain itu limbah padat seperti cangkang digunakan sebagai bahan bakar boiler untuk pembangkit uap serta bahan baku karbon aktif. Namun pemanfaatan limbah dengan metode seperti ini hanya dapat menanggulangi limbah dalam skala kecil sedangkan limbah padat diproduksi dalam skala yang cukup besar (Miura et al, 2003). Untuk itu diperlukan suatu terobosan yang dapat mengolah limbah padat sawit. Karena limbah padat sawit mempunyai potensi sebagai sumber energi, maka pada penelitian ini menggunakan limbah padat sawit (batang kelapa sawit, tandan kosong dan pelepah) sebagai biomasa untuk memproduksi bio-oil.

Pemilihan limbah padat sawit pada penelitian ini karena Riau merupakan salah satu propinsi yang memiliki perkebunan kelapa sawit yang luas serta komponen kelapa sawit seperti batang, daun, tandan kosong mengandung holoselulosa yang cukup tinggi (batang 86,03\%, daun 69,86\%, tandan kosong 73,85\%, akar 67,89\%) (Anderson \& Khalid 2000). Kandungan holoselulosa ini akan berpengaruh pada kecepatan pembentukan produk, semakin tinggi kandungan selulosa maka pembentukan produk akan lebih tinggi (Song et al, 2000).

Proses yang digunakan dalam memproduksi biooil adalah slow pyrolysis. Slow pyrolysis merupakan proses dimana partikel-partikel bahan organik atau biomassa diberikan pemanasan secara cepat pada suhu antara $450-600^{\circ} \mathrm{C}$ tanpa adanya kandungan oksigen dalam proses. Dari proses tersebut diperoleh uap organik, gas dan arang. Uap organik dikondensasikan menjadi bio-oil dengan hasil mencapai 38-60\% berat dari umpan yang dimasukkan (Goyal et al, 2006).

\section{BAHAN DAN METODE}

Bahan yang digunakan dalam penelitian ini adalah limbah padat sawit yang terdiri dari :batang, tandan kosong dan pelepah. Bahan lain yang digunakan adalah gas nitrogen. Sedangkan alat yang digunakan adalah furnace turbular, pipa stainless steell (sebagai reaktor), kondenser, oven, pignometer, viskometer ostwald, statip, beaker glass, kertas indikator universal, Bubble flow meter.

Limbah padat sawit yang digunakan terlebih dahulu dipotong kecil-kecil. Limbah padat sawit yang telah dihaluskan kemudian diayak menggunakan ayakan dengan ukuran 2, 6, dan 10 mesh, sehingga diperoleh biomassa dengan ukuran 6-10 mesh dan 2-6 mesh. Selanjutnya limbah padat sawit yang telah dihaluskan dimasukkan ke dalam oven untuk menghilangkan kadar air limbah padat sawit sampai kelembaban kurang dari $10 w t \%$ (BTG 2004).

Selanjutnya partikel biomassa diproses dengan proses pyrolisis. Dalam proses pyrolisis digunakan reaktor yang terbuat dari pipa stainless steel dengan diameter 1,5 in $(3,81 \mathrm{~cm})$ dan panjang $60 \mathrm{~cm}$. Reaktor dipanaskan menggunakan furnace turbular dengan cara mengatur temperatur furnace sehingga mencapai temperatur operasi $450,500,550$, dan $600^{\circ} \mathrm{C}$.

Limbah padat sawit yang telah dihaluskan sebanyak $45 \mathrm{~g}$ dimasukkan ke dalam reaktor. Selanjutnya gas nitrogen dialirkan ke dalam reaktor dengan kecepatan $1 \mathrm{~mL} / \mathrm{s}$. Uap organik yang dihasilkan dikondensasi menggunakan kondenser untuk mendapatkan cairan yang dinamakan bio-oil. Proses berlangsung sampai tidak terlihat lagi uap organik atau cairan yang keluar dari hasil kondensasi.

Bio-oilyang dihasilkan selanjutnya ditentukan $\mathrm{pH}$ dan densitasnya masing-masing menggunakan kertas indikator dan pignometer. Untuk menentukan komponen yang terkandung dalam bio-oil, dilakukan analisa menggunakan gas chromathograpy.

\section{HASIL DAN PEMBAHASAN}

Pengaruh temperatur terhadap Bio-oil yang dihasilkan. Gambar 1 memperlihatkan hubungan temperatur terhadap bio-oilyang dihasilkan. Pengaruh temperatur dipelajari pada suhu 450, 500, 550 dan 


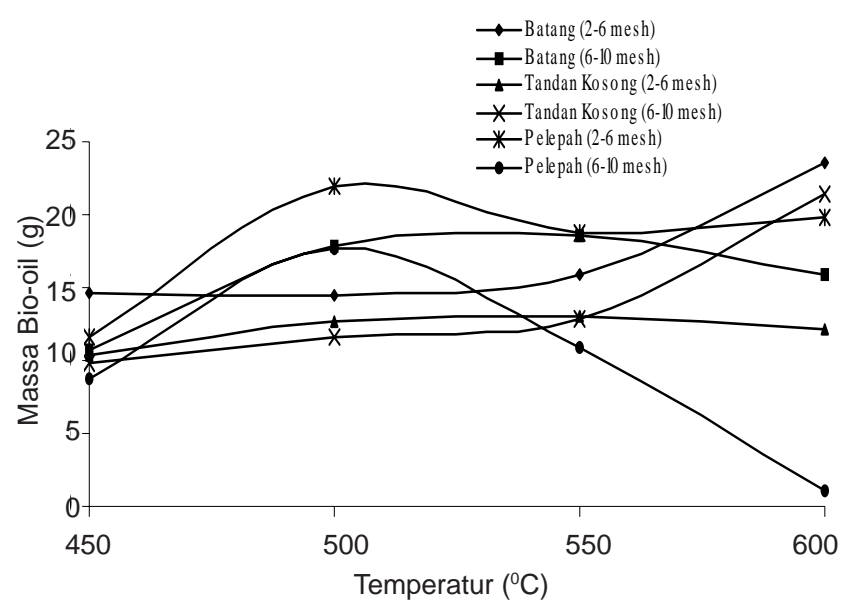

Gambar 1. Hubungan antara temperatur dengan massa biooil yang dihasilkan.

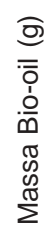

450

$$
500 \underset{\text { Temperatur }\left({ }^{\circ} \mathrm{C}\right)}{550}
$$

Gambar 2. Perbandingan jumlah bio-oil dan char yang dihasilkan pada suhu tertentu.

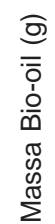

$$
\begin{aligned}
& 500 \\
& \text { Temperatur }\left({ }^{\circ} \mathrm{C}\right) \\
& 550
\end{aligned}
$$

Gambar 3. Hubungan jumlah bio-oil yang dihasilkan untuk variasi biomassa dengan ukuran 2-6 mesh

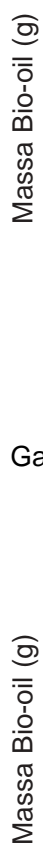

$$
\text { Temperatur }\left({ }^{\circ} \mathrm{C}\right)
$$

Gambar 4 Hubungan jumlah bio-oil yang dihasilkan untuk variasi biomassa dengan ukuran 6-10 mesh.

$$
\text { Temperatur }\left({ }^{\circ} \mathrm{C}\right)
$$

Gambar 5. Hubungan ukuran partikel batang sawit dengan massa bio-oil.

600

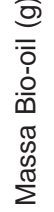

500 Temperatur $\left({ }^{\circ} \mathrm{C}\right)$
600

Gambar 6. Hubungan ukuran partikel tandan kosong sawit dengan massa bio-oil.

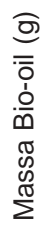

450

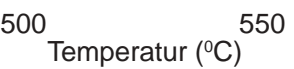

Gambar 7. Hubungan ukuran partikel pelepah sawit dengan massa bio-oil 


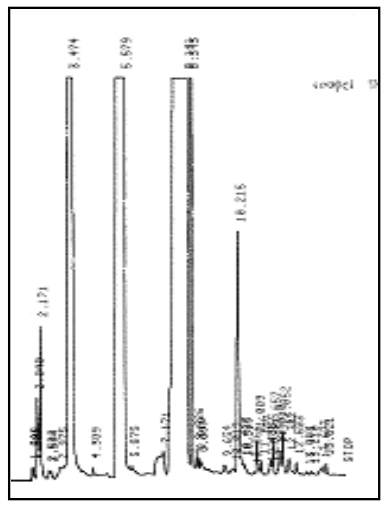

Gambar 8. Waktu retensi sampel tandan kosong sebelum ditambah BTX (a) dan setelah ditambahkan BTX (b)

$600^{\circ} \mathrm{C}$. Sedangkan Gambar 2 memperlihatkan perbandingan yield bio-oildan charyang dihasilkan pada suhu tertentu. Secara teoritis, yield bio-oil akan meningkat dengan meningkatnya suhu dan charakan berkurang dengan menurunnya suhu. Yield maksimum yang diperoleh pada suhu $500^{\circ} \mathrm{C}$.

Dari Gambar 1 terlihat bahwa dari penelitian yang dilakukan, yield bio-oil maksimum diperoleh pada suhu $500^{\circ} \mathrm{C}$ kecuali untuk batang 6-10 mesh dan pelepah 610 mesh. Hal ini terjadi karena kandungan holoselulosa

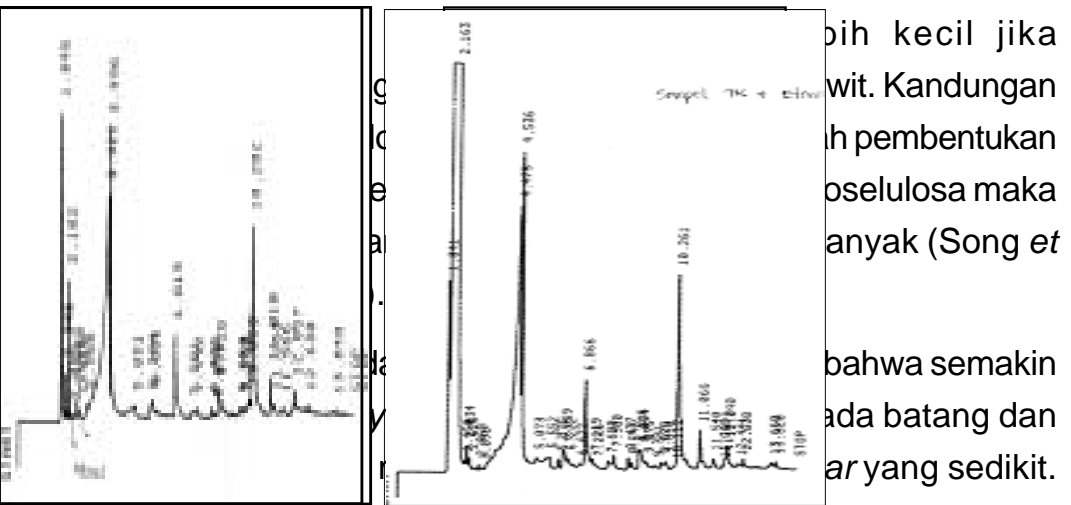

Hal ini terjadi karena char merupakan uap organik yang tidak dapat terkondensasi menjadi bio-oil. Jadi semakin banyak uap organik yang terkondensasi maka char yang dihasilkan akan semakin sedikit.

Pengaruh jenis limbah sawit terhadap massa

bio-oil. Biomassa yang digunakan pada penelitian ini adalah limbah padat sawit meliputi: batang, tandan kosong dan pelepah. Perbandingan jumlah bio-oilyang dihasilkan disajikan pada Gambar 3 dan 4. Gambar 3 memperlihatkan bahwa bio-oil terbanyak diperoleh pada batang kelapa sawit pada suhu $600^{\circ} \mathrm{C}$. Sedangkan pada pelepah dan tandan kosong, bio-oil lebih banyak dihasilkan pada suhu $500^{\circ} \mathrm{C}$. Namun pada gambar 4 terlihat bahwa bio-oil lebih banyak dihasilkan oleh

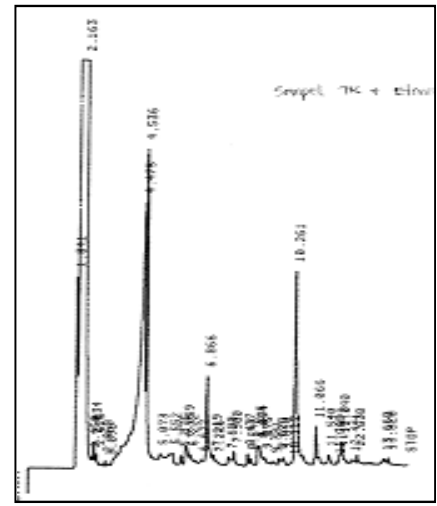

Gambar 9. Waktu retensi tandan kosong sebelum ditambah etanol (a) dan setelah ditambah etanol(b)

tandan kosong pada suhu $600^{\circ} \mathrm{C}$ sedangkan untuk pelepah dan batang kelapa sawit, bio-oil yang dihasilkan lebih banyak pada suhu $500^{\circ} \mathrm{C}$. Namun secara keseluruhan bio-oil yang tertinggi diperoleh dari batang kelapa sawit. Secara teoritis, semakin besar kandunga holoselulosa maka pembentukan produk (biooi) akan semakin tinggi. Berdasarkan data, kandungan holoselulosa batang kelapa sawit lebih besar dari pada limbah padat sawit lainnya (Anderson \& Khalid 2000).

Pengaruh Ukuran Partikel Terhadap bio-oil.

Pengaruh ukuran partikel padatan sawit terhadap biooil yang dihasilkan dapat dilihat pada Gambar 5, 6 dan 7 berturut-turut adalah batang, tandan kosong, dan pelepah.

Dari Gambar 5, 6, dan 7 terlihat pengaruh ukuran partikel terhadap bio-oil yang dihasilkan. Secara keseluruhan untuk beberapa percobaan biomassa dengan ukuran 2-6 mesh menghasilkan bio-oil yang lebih banyak daripada biomassa dengan ukuran 6-10 mesh. Hal ini disebabkan karena pada biomassa dengan ukuran kecil, gas $\mathrm{N}_{2}$ tidak dapat masuk secara merata pada keseluruhan rongga. Sedangkan untuk biomassa dengan ukuran 2-6 mesh, bio-oil akan lebih mudah terbentuk karena gas $\mathrm{N}_{2}$ dapat masuk secara merata pada keseluruhan rongga antar biomassa. Sehingga akan mengurangi jumlah oksigen yang terdapat dalam reaktor. Dengan adanya oksigen dalam reaktor, maka akan terjadi pembakaran yang akan menghasilkan arang dan mengurangi jumlah bio-oil yang dihasilkan.

Analisa kromatografi. Analisa menggunakan gas chromatography HP 5890 II. Untuk menentukan kandungan yang terdapat dalam bio-oil, analisa dilakukan dengan metoda standar adisi (penambahan 
etanol dan BTX -benzene, toluene dan xylem- pada sampel tandan kosong). Hasil analisa disajikan pada Gambar 8 dan Gambar 9.

Gambar 8 memperlihatkan hasil analisa sampel menggunakan gas choromatography sebelum dan sesudah penambahan standar adisi. Dari gambar 8 dapat diduga bahwa bio-oil yang dihasilkan mengandung benzene, toluene dan xylen (puncak yang standat adidi lebih tinggi dibandingkan dengan yang tanpa adisi). Sedangkan Gambar 9 memperlihatkan sampel sebelum dan sesudah ditambah etanol. Sama halnya dengan Gambar 8. Karena setelah penambahan standar adisi puncak dominan naik seiring dengan penambahan standar dibanding tanpa penambahan standar.

Dari hasil penelitian yang telah dilakukan ini, dapat dilihat bahwa limbah padat sawit merupakan biomassa yang sangat berpotensi menghasilkan liquid yang dapat didefenisikan sebagai bio-oil yang dapat digunakan sebagai bahan bakar. Secara teoritis, kandungan etanol yang terdapat dalam bio-oil merupakan bahan dasar untuk dijadikan bahan bakar. Bio-oil yang dihasilkan memiliki sifat-sifat sebagai berikut:

n $\quad: 0,99-1,1 \mathrm{~g} / \mathrm{mL}$

$\mathrm{pH}: 3$

Hal ini disebabkan oleh asam asetat yang terdapat dalam bio-oil.

Warna : Coklat tua

Bau : Asap

\section{KESIMPULAN}

Bio-oil yang dihasilkan akan meningkat dengan meningkatnya suhu dan char yang dihasilkan akan semakin menurun dengan meningkatnya suhu. Bio-oil maksimum diperoleh pada suhu $500^{\circ} \mathrm{C}$ dan ukuran partikel biomassa 2-6 mesh. Analisa bio-oil dengan gas chromatography terindentifikasi juga adanya etanol, benzene, toluene dan xylen.

\section{UCAPAN TERIMAKASIH}

Pada kesempatan ini kami ingin mengucapkan terima kasih kepada mahasiswa dan semua Laboran, yang telah membantu kami dalam menyelesaikan penelitian ini.

\section{DAFTAR PUSTAKA}

Anderson \& Khalid. 2000. Decomposition processes and nutrient release patterns of oil alm residu. Journal of Oil Palm Research 12: 46-63.

Bain \& Richard, L. 2004. An Introduction to Biomass Thermochemical Conversion. DEO/NASLUGC Biomass and Solar Energy Workshop. August 3-4

Beis, S. H., Onay, O. \& Kockar, O. M. 2002. Fixed bed pyrolysis of safflower seed: influence of pyrolysis parameter on product yields \& compositions. Journal Renew Energy 26: 21-32.

Goyal, H. B., Seal, D. \& Saxena, R. C., 2006, Bio-fuels from Thermochemical Conversion of Renewable Resources: A review, Renewable and Sustainable Energy Reviews.

Miura, K., Masuda, T., Funazukuri, T., Suguwara, K., Shirai, .Y, Hayashi, J., Karim, M. I, A., Ani \& F.N.Susanto, H. 2003. Efficient Use of Oil Palm as Renewable Resource for Energy \& Chemical. Project Design Document.

Kartasasmita, G. 1992. Sumber energi yang tersedia cukup untuk ratusan tahun. Pusat Pengembangan Tenaga Perminyakan Gas Bumi 8: 4-8.

Onay, O. \& Kokar, O. M. 2004, Fixed bed pyrolysis of rapeseed (Brassica napus L). Journal Biomass Bioenergy 26: 289299.

Ozbay, N., Putun, A. E., Uzun, B. V. \& Putun, E., 2001, Biocrude from biomass: pyrolysis of cotton seed cake. Jounal Renew Energy 24: 615-625.

Song, C., Hu H., Wang, G. \& Chen, G. 2000. Liquefaction of Biomass with Water in Sub - and Supercritical States. Scientific Research Fund For Doctoral Award Unit In Chinese University.

Suwono,.A. 2003. Indonesia's Potential Contribution of Biomass in Sustainable Energy Develompment. Thermodynamics Laboratory. IURC for Engineering Sciences. Bandung Institute of Technology. Bandung: Indonesia. 